\title{
An Analysis of the Challenges Towards the Practices of Electronic Banking in Cooperative Bank of Oromia Mida Kegn Branch, Oromia Regional State, Ethiopia
}

\author{
Mr. Atinafu Abera Mr. Telila Elias Dr A Tamilarasu \\ Department of Cooperatives, (ICDS) Ambo University, Ethiopia
}

\begin{abstract}
The aim of this paper was to assess the Challenges of Electronic banking practices in Cooperative Bank of Oromia Mida Kegn Branch, Oromia Regional State, Ethiopia. The study was conducted based on the data gathered from Cooperative Bank of Oromia Mida Kegn Branch (CBO). A mixed research approach was used to answer the research questions that emerge through the review of existing literature and the experiences of the researcher in respect of the E-Banking system in Ethiopia. The study statistically analyzes data obtained from the survey questionnaire. The study was conducted on Mida Kegn Branch and 154 customers were selected by Simple Random Sampling. The data gathered through primary method was summarized using descriptive statistics through frequency distribution and percentages, mean and standard deviation, Pearson Correlation to come up the analyses of data. Mean score is used to identify the highest and the lowest of the variables. Pearson's Correlation analysis is used to test the degree of the relationship between independent variables and the dependent variable. The study also suggests a series of measures which could be taken by the Cooperative Bank of Oromia Mida kegn Branch and to address various challenges identified in the study area.
\end{abstract}

Keywords: Challenges; Cooperative Bank of Oromia; E-Banking Adoption; Electronic Banking Practices

DOI: $10.7176 /$ RJFA/12-7-01

Publication date: April $30^{\text {th }} 2021$

\section{INTRODUCTION}

\section{Background of the Study}

Nowadays modern technology is being introduced in all fields and it is changing the world with full of innovations. In this regard, information technology is considered as the key driver for the changes to take place around the world. The traditional banking services are getting modernized by the use of electronic banking. These changes are made mainly due to the developments in Information and Communication Technology. (Shittu, 2010).

Electronic banking enables a customer to do banking transactions through the bank's website in the internet. It is more or less like bringing the bank to customer's computer, at the place and time of customer's choice. (Devamohan, 2012).

The rapidly growing information and communication technology is knocking the front door of every bank in the world, where Ethiopian banks would never be exceptional. Electronic Banking has been widely used in developed countries and is rapidly expanding in developing countries. In Ethiopia, however, in this context, the study was attempt to trace the present status of E-Banking in Cooperative Bank of Oromia Mida Kegn Branch, Oromia Regional State, Ethiopia the prospects and practices and looks at the challenges faced in providing the service.

\section{Statement of the problem}

Electronic banking is a driving force that is changing the banking industry towards a more competitive and efficient situation. Electronic banking presents both an opportunity and a challenge in terms of being able to provide the convenience, efficiency, and effectiveness of electronic banking to its customers. (Alam, 2010).

The main driver behind electronic banking is convenience. It is available around the clock, is extremely time-saving, and is accessible from anywhere around the world. Electronic banking is very efficient, and has helped cut down a lot of costs, and in the case of virtual banks it has cut down almost all costs (Alam, 2010).

According to Kumaga (2010), low level of internet penetration and poorly developed telecommunication infrastructure impede smooth development and improvements in E-commerce in developing countries.

Despite the growth of E-Banking worldwide, most Cooperative Bank of Oromia continues to conduct most of their banking transactions using traditional teller based methods. Despite the fact that E-Banking has a lot of benefit for both banks and customers in Oromia, Banking operation is still under developed backed by low level of infrastructural development, lack of suitable legal and regulatory framework, high rates of illiteracy, frequent power interruption and security issues. Moreover, E-Banking is a new technology in Ethiopia which needs a lot of effort and resources to be easily adopted by customers (Yitbarek, 2013).

The adoption and growth of Electronic Banking is found to be very important towards creating a cashless 
society with its impact on bringing economic transparency, efficiency and growth. From customers' perspective, the most recognized drivers for the growth of Electronic Banking include convenience, reliability, widely availability, affordability and usefulness of the services (CBO, 2017/18).

Hence, in order to help banks to improve E-Banking adoption by their customers, it is necessary to examine challenges to adopt E-Banking service of Cooperative Bank of Oromia MidaKegn Branch.

\section{Objectives of the Study}

To examine the challenges of E-Banking Practices in the study area.

\section{Review of related literature reviewed \\ E- Banking}

E-Banking includes the systems that enable financial institution customers, individuals or businesses, to access accounts, transact business, or obtain information on financial products and services through a public or private network, including the Internet. Customers access E-Banking services using an intelligent electronic device, such as Point of Sale (POS), Automated Teller Machine (ATM), Short Message Services (SMS) and Mobile Banking (Shannak, 2013).

\section{Mobile Banking}

Mobile Banking is a service that enables customers to conduct some banking services such as account inquiry and funds transfer, by using of Short Text Message (STM). Mobile Banking can be defined as an occurrence when customers access a bank's networks using cellular phones, pagers, personal digital assistants, or similar devices through telecommunication wireless networks (Segun, 2011).

\section{Tele-Banking}

According to Habibur, Mohammed and Sayeed (2012) Telephone Banking service is provided by phone. To access an account it is required to dial a particular telephone number and there are several options of services. Options included; Checking account balance, Funds transfer between current, savings and credit card accounts, Bill Payments, Stock exchange transaction, Receive statement via fax and Loan payment information.

Another relevant study conducted by (Yitbarek and zeleke, 2013) on analysis of factors influencing customers' intention to the adoption of E-Banking service channels by using research model of Technology Acceptance Model (TAM) revealed that attitude, subjective norm, perceived behavioral control, perceived usefulness and perceived ease of use and perceived risk were significant in affecting users' intention to use EBanking service channels. In general, Review of Empirical studies shows that understanding the Critical Success Factors (CSFs) in E-Banking is important for banking industries because it would potentially help them improve their strategic planning process.

\section{The gap of the study}

As reviews reviewed from many researches studied, many of them were studied factors determining for the adoption of E- banking services, but still little studies are available in Ethiopia also but there is no study available in the study area, study unit related to the challenges for the E- banking practices in cooperative bank of Oromia Mida Kegn Branch, Oromia Regional State, Ethiopia

\section{Research Design}

To attain the intended objective of this study, Descriptive Research Design was employed. It is descriptive research design because it aims to describe, contrast and analyze the problem identified and to describe the relationship between the E-Banking variables and customer satisfaction and how these dimensions affect customer satisfaction.

\section{Types and Sources of Data}

In this study, both primary and secondary data sources were employed. The data type of the study was crosssectional data since the Research on the challenges and prospects of E- Banking practices in the case of Cooperative Bank of Oromia MidaKegn Branch.

\section{Sources of Data}

The data required for the study is obtained from primary and secondary sources.

\section{Primary Data Source}

Primary data source is required in order to get first-hand information with respect to the study under consideration. Primary data was collected from the sample customers' respondents by using questionnaire. The 
structured questionnaires were developed in English.

\section{Data Collection Techniques}

Two types of instruments were used in this study in order to collect both qualitative (by interviews) and quantitative data (by questionnaires). The primary data was collected through questionnaire. The questionnaire was administered through trained data collectors using interview type. With regard to the questionnaire, the questions are both open ended and close ended.

\section{Sampling Techniques}

The method of sampling techniques that was employed in this study is Simple Random Sampling. Because it is chosen in order to avoid bias. In Simple Random Sampling by its nature, each element in the population has an equal chance of being included in the sample. The sample item comprised of the customers of the Bank and Bank officials in the study unit and in the study area.

\section{Populations of the Study}

The target populations of the study area are: - Bank staffs16, Bank's customers 13,931 and the total are 13,947.They are 10,695 customers are using electronic banking and 3,252 are non-using Electronic Banking. The researcher, study only the customers who uses Electronic Banking only.

\section{Method of sample size determination}

Multi stage sampling was used.

The Cooperative Bank of Oromia has more than360 Branches and Midakegn Branch is one of the Nekemte districts of CBO that has 10 branches under its domain. Out of these 360 branches, the study was conducted in Mida Kegn Branch and 154 customers were also selected on Simple Random Sampling Method because of large numbers of CBO's customers.

For the purpose of this study, based on population size, sampling error (the level of precision) the confidence level, finance and time available for the researcher, sample size was determined by Yamane formula in a scientific way. $\quad \mathrm{N}=10,695 \quad \mathrm{e}=0.08 \quad \mathrm{Z}=92 \%$ Hence, following formula is used.

$$
n=\frac{N}{1+N(e)^{2}}=\frac{10,695}{1+10,695(0.08)^{2}}=\underline{154}
$$

Where $N$ is the population size, $\mathrm{n}$ is sample size, $\mathrm{Z}$ is the confidence level and $e$ is the level of precision or sampling error.

Since in a social science, $1 \%-10 \%$ of errors are acceptable, for the purpose of this study, the researcher was accept $8 \%$ of error due to of lack time and fund to collect data from large sample(Admaset al,2007).

\section{Method of Data Analyzing}

The data that was gathering through primary method was summarizing using descriptive statistics through frequency distribution and percentages, mean and standard deviation, Pearson Correlation to come up the analyses of data. Mean score is used to identify the highest and the lowest of the variables. Pearson's Correlation analysis is used to describe the magnitude/degree of association between independent variables and the dependent variable.

In order to meet the stated research objectives, the collected data is analyzed based on the nature of the objective. Accordingly, the data collected via questionnaires is analyzed with descriptive statistics using Statistical Package for the Social Sciences (SPSS) V. 20.0.

Table- 1 - The type of E-Banking Channels Used by Customers

\begin{tabular}{llll}
\hline \hline E-Services & Frequency & Valid Percent & Cumulative Percent \\
\hline \hline ATM & 121 & 78.6 & 78.6 \\
SMS & 8 & 8.4 & 87.0 \\
POS & 8 & 2.6 & 92.2 \\
Mobile Banking & 13 & 5.2 & 94.8 \\
Internet Banking service & 8 & 5.2 & 100.0 \\
\hline \hline Total & 154 & 100.0 & \\
\hline
\end{tabular}

Source : Primary Data- 2019

It is witnessed from the above table 1- that out of 154 respondents, the majority of them $121(78.6 \%)$ were used ATM services as the E- banking services and 13(5.2\%) of them were used mobile banking services, 8 $(5.2 \%)$ of them were used invariably the services of SMS (Short Message Systems), POS (Point of Sale) and 
internet banking services in the study area and in the study unit. However, ATM and Mobile banking services are most dominantly used E-Banking services in the study area.

Table 2- Kind of Services Availed by the Respondents

\begin{tabular}{lcccc}
\hline \hline Kinds of services Availed & Frequency & Valid Percent & Mean & Std. Deviation \\
\hline \hline Fund Transfer & 57 & 37.0 & 2.0714 & .99743 \\
Balance Checking & 40 & 26.0 & & \\
Withdrawal of Cash & 43 & 27.9 & \\
Purchase of Goods & 14 & 9.10 & & \\
\hline \hline & & & \\
Total & 154 & 100.0 & \\
\hline \hline
\end{tabular}

Source: Primary Data- 2019

The result presented in the above table shows that, the respondents asked whether customers of Kinds of services from the banks, and the descriptive statistics result gives mean and SD of 2.0714 \&.99743 respectively, that means the largest number of respondents were agreed on the issue, therefore Kinds of services of the customers used were for fund transfer followed by withdrawal of cash from the accounts. This result were consistent with the findings of Ghazi and Khalid (2012, p.9); Khalfanet al (2006) in which all indicted that, the kinds of services, such as

Table: 3. Major Challenges for E-Banking Practices

\begin{tabular}{|l|r|r|r|}
\hline Challenges for E-Banking Practices & Frequency & Valid Percent & Cumulative Percent \\
\hline Lack of knowledge & 36 & 23.4 & 23.4 \\
Electricity Problems & 15 & 9.7 & 33.1 \\
Network Problems & 38 & 24.7 & 57.8 \\
Less number of ATM machines & 65 & 42.2 & 100.0 \\
Total & 154 & 100.0 & \\
\hline
\end{tabular}

Source: Primary Data- 2019

The above table -3. Shows that the largest number of respondents $65(42.2 \%)$, were agreed with the idea that lack of competition between Ethiopian banking sector and foreign bank is considered as barrier for the adoption of E-Banking system. Similarly, an interview result revealed that, Ethiopian government did not allow foreign banks to operate in the country, these is due to protecting of local banks from the well-developed foreign bank competition. Therefore, Ethiopian banking industry did not consider about competition with foreign banks and such policies could discourage banking sector of the country from the adoption of E-Banking system.

Table: 4. Mean Comparison Statistical Summary

\begin{tabular}{|ll|c|c|r|r|}
\hline Paired Samples Statistics & Mean & N & Std. Deviation & Std. Error Mean \\
\hline \multirow{2}{*}{ Pair 1 } & Challenges of E-banking practices & 2.2597 & 154 & .59194 & .04770 \\
& Security of E-banking & $\mathbf{3 . 6 7 5 3}$ & 154 & .89941 & .07248 \\
Pair 2 & Challenges and prospects of E-banking practices & 2.2597 & 154 & .59194 & .04770 \\
& Role of GOV'T to adopt technology & $\mathbf{2 . 2 1 4 3}$ & 154 & 1.12002 & .09025 \\
Pair 3 Challenges and prospects of E-banking practices & 2.2597 & 154 & .59194 & .04770 \\
& Technological Factor & $\mathbf{2 . 4 0 2 6}$ & 154 & 1.47094 & .11853 \\
Pair 4 & Challenges and prospects of E-banking practices & 2.2597 & 154 & .59194 & .04770 \\
& Organizational Factor & $\mathbf{3 . 0 3 2 5}$ & 154 & 1.35964 & .10956 \\
Pair 5 & Challenges and prospects of E-banking practices & 2.2597 & 154 & .59194 & .04770 \\
& Environmental Factor & $\mathbf{1 . 6 6 8 8}$ & 154 & .47217 & .03805 \\
Pair 6 & Challenges and prospects of E-banking practices & 2.2597 & 154 & .59194 & .04770 \\
& Lack of Adequate ICT Infrastructure & $\mathbf{2 . 4 3 5 1}$ & 154 & .83177 & .06703 \\
Pair 7 Challenges and prospects of E-banking practices & 2.2597 & 154 & .59194 & .04770 \\
& Environmental Factor(Lack of Competition & $\mathbf{2 . 5 3 2 5}$ & 154 & 1.22164 & .09844 \\
\hline
\end{tabular}

Source: Primary Data- 2019

In order to address the objective on testing the statistical significance difference between two different variables on some E-Banking challenges indicators of some $\mathrm{CBO}$; variables such as technological factor, organizational factor, environmental factor, lack of adequate infrastructure, Environmental factor (lack of competition of E- Banking with the period in which E-Banking was so as to compare the mean of each performance indicators. Accordingly, the Technological factor(Mean value= 2.4026), organizational factor(mean value $=3.0325)$, environmental factor $($ mean value $=1.6688)$, lack of adequate infrastructure $($ mean value $=2.4351)$, environmental factor (lack of competition) mean value= 2.5325 respectively of $\mathrm{CBO}$ implementation of EBanking for the E-Banking is estimated as to be favor for the practices of the E- banking services. 
Table : 5.Correlations between Dependent and independent variables

\begin{tabular}{|c|c|c|c|c|c|c|c|c|c|}
\hline & & GOVR & EXP & TECHF & OF & DMOGF & LAIS & $\mathrm{EF}$ & ES \\
\hline Challenges and prospects & $\begin{array}{c}\text { Pearson } \\
\text { Correlation }\end{array}$ & 1 & & & & & & & \\
\hline of E-banking practices & Sig. (2-tailed) & & & & & & & & \\
\hline & $\mathrm{N}$ & 154 & & & & & & & \\
\hline & Pearson & $.744^{* *}$ & 1 & & & & & & \\
\hline adopt technology & Sig. (2-tailed) & .000 & & & & & & & \\
\hline & $\mathrm{N}$ & 154 & 154 & & & & & & \\
\hline (2) Expecting from the & Pearson & $.825^{* *}$ & $.910^{* *}$ & 1 & & & & & \\
\hline bank to provided efficient & Sig. (2-tailed) & .000 & .000 & & & & & & \\
\hline e-banking services & $\mathrm{N}$ & 154 & 154 & 154 & & & & & \\
\hline & Pearson & $.817^{* *}$ & $.939^{* *}$ & $.919^{* *}$ & 1 & & & & \\
\hline (3) Technological Factor & Sig. (2-tailed) & .000 & .000 & .000 & & & & & \\
\hline & $\mathrm{N}$ & 154 & 154 & 154 & 154 & & & & \\
\hline & Pearson & $.680^{* *}$ & $.918^{* *}$ & $.786^{* *}$ & $.873^{* *}$ & 1 & & & \\
\hline (4)Organizational Factor & Sig. (2-tailed) & .000 & .000 & .000 & .000 & & & & \\
\hline & $\mathrm{N}$ & 154 & 154 & 154 & 154 & 154 & & & \\
\hline & Pearson & $.497^{* *}$ & $.765^{* *}$ & $.557^{* *}$ & $.673^{* *}$ & $.842^{* *}$ & 1 & & \\
\hline (5) Demographic factors & Sig. (2-tailed) & .000 & .000 & .000 & .000 & .000 & & & \\
\hline & $\mathrm{N}$ & 154 & 154 & 154 & 154 & 154 & 154 & & \\
\hline (6) Lack of Adequate ICT & $\begin{array}{l}\text { Pearson } \\
\text { Correlation }\end{array}$ & $.658^{* *}$ & $.881^{* *}$ & $.837^{* *}$ & $.860^{* *}$ & $.901^{* *}$ & $.702^{* *}$ & 1 & \\
\hline Infrastructure & Sig. (2-tailed) & .000 & .000 & .000 & .000 & .000 & .000 & & \\
\hline & $\mathrm{N}$ & 154 & 154 & 154 & 154 & 154 & 154 & 154 & \\
\hline (7).Environmental & $\begin{array}{l}\text { Pearson } \\
\text { Correlation }\end{array}$ & $.820^{* *}$ & $.886^{* *}$ & $.916^{* *}$ & $.909^{* *}$ & $.824^{* *}$ & $.648^{* *}$ & $.819^{* *}$ & 1 \\
\hline Factor(Lack of & Sig. (2-tailed) & .000 & .000 & .000 & .000 & .000 & .000 & .000 & \\
\hline & $\mathrm{N}$ & 154 & 154 & 154 & 154 & 154 & 154 & 154 & \\
\hline
\end{tabular}

**. Correlation is significant at the 0.01 level (2-tailed).

Source: Primary Data- 2019

Table above depicts the correlation between the independent variables and also with the dependent variables. The result shows the acceptable reliability of the research variables in which, the correlation among predictors were not high indicates there are no problems among variables. As of the relationships between the dependent variables (Challenges of E-Banking practices) and independent variables (EF, DMOGF, OF, TECHF, GOV'T and EXP), some findings are significant and Furthermore, there were strong correlations between the dependent variable(Challenges and prospects of E-Banking practices ) and independent variables $\mathrm{EF}(\mathrm{r}=0.819)$ DMOGF $(r=0.842) \quad$ OF $(r=0.873)$, TECHF, $(r=0.919)$ GOVR $(r=0.744)$ and EXP $(r=0.910)$, with $(\mathrm{P}<0.01)$ level of significant, shows a strong support for first, fourth and six respectively. The correlation analysis was utilized to reject or accept research in previous E-Banking research in addition to the regression analysis.

\section{Important findings and Recommendations}

Based on the above data analysis and interpretations the following recommendations were the made from the findings of the study and it has been forwarded to the stakeholders:

In order to exploit the benefits that can be achieved from the provision of E-Banking services, banks operating in the country needs to establish a strong link with customers by providing the required information that will enable them to use electronic banking services in the future. In this regard, it is recommendable to make website information clear and precise so that customers can easily understand about the service. Furthermore, since it is the duty of the concerned staff to provide all the information to its customers, they should provide all the materials to customers that demonstrate how to use electronic banking.

The findings reveal that security \& privacy are the most important issues for customers to use electronic banking. In this regard, the two commercial banks should provide security measures to their customers that demonstrates full authentication, privacy, completion of transaction from start to end and its confirmation. 
Moreover, these two banks should acquire latest computer programs that enable banks to have a powerful technique for security related issues.

For the successful implementation of E-Banking system telecommunication infrastructure, is a major prerequisite. Therefore, the government should support the electronic banking sector by investing on telecommunication infrastructure development. In this regard, (ETC) Ethio-Tele-Com needs to provide these banks to have a better and quality network having a higher bandwidth. By doing so, the existing quality of internet connection should also be improved until such time that successful implementation is achieved.

Without technology it is impossible for banks to compete and provide quality services. It is also very important that the existing IT employees of the study units and the study area should learn new skills. It is also strongly recommended that study units have to hire well trained and experienced IT professionals to handle the business competently and who are capable of solving the problems with adequate knowledge in technology.

The finding of the study also indicated that CBO had lacked fast and effective compliant handling system. And therefore; the bank should establish efficient and effective compliant handling system in the future in order to retain the existing E-Banking customers and to attract new customers (E-Banking users).

Therefore, Ethiopian government should establish a clear set of legal frame work on the use of technology in banking industry, support banking industry by investing on ICT infrastructure and banks needs to be focused on technological innovation competition rather than traditional bases of retail bank competition in the study area to overcome the challenges faced by the study units and the study area in general and for the improvement of the E- banking services in the country as well..

\section{References;}

Alam N. (2010). Challenges Faced by Sudanese Banks in Implementing Online Banking: Bankers' Perception, Journal of Internet Banking and Commerce, vol. 15, no.2, pp.2.

Devamohan, A (2012).Lecture Note on E -Banking -Problems and Prospects in Ethiopia, Jimma University, Unpublished document.

Kumaga, D. (2010). The challenges of implementing Electronic Payment Systems - The Case of Ghana's Ezwich Payment System. Unpublished

Shittu, O. (2010). The Impact of Electronic Banking in Nigeria Banking System: Critical Appraisal of Unity Bank PLC. Ladoke Akintola University of Technology, Ogbomoso, Nigeria.

Segun, A. (2011) Mobile Banking to Transform Nigeria's Economy, says GT Bank Boss THISDAYLIVE [online], Available at: http://www.thisdaylive.com/articles/mobilEbanking-

Shannak, R. O. (2013). Key Issues in E-Banking Strengths and Weaknesses: The Case of Two Jordanian Banks. European Scientific Journal March 2013 Edition Vol.9, No.7 ISSN: 1857 - 7881 (Print) E - ISSN 1857- 7431, 1-25.

YitberekZeden, (2013). Online digital payment system a thesis submitted to Addis Ababa University assessed on www. aau.edu.et. 